\title{
A family of immunologically related transcription factors that includes multiple forms of ATF and AP-1
}

\author{
Tsonwin Hai, ${ }^{1}$ Fang Liu, ${ }^{1}$ Elizabeth A. Allegretto, ${ }^{2}$ Michael Karin, ${ }^{2}$ and Michael R. Green ${ }^{1}$ \\ ${ }^{1}$ Department of Biochemistry and Molecular Biology, Harvard University, Cambridge, Massachusetts 02138 USA; \\ ${ }^{2}$ Department of Pharmacology M-036, Center for Molecular Medicine, University of California at San Diego, La Jolla, \\ California 92093 USA
}

\begin{abstract}
ATF is a cellular transcription factor involved in the regulation of multiple adenovirus E1A- and cellular cAMP-inducible promoters. Using DNA affinity chromatography, we have purified ATF and found that a series of polypeptides copurify in a sequence-specific manner. We demonstrate that these polypeptides represent a family of proteins that are related by DNA-binding specificity and by immunological cross-reactivity. This family includes the transcription factor AP-1, whose recognition sequence, GTGAGT ${ }_{A} A$, differs from the ATF consensus, GTGACGTC ${ }_{A} A$, by the absence of a cytosine residue. Our results further indicate that there are multiple forms of both ATF and AP-1. The immunological cross-reactivity and related DNA-binding specificities suggest that ATF and AP-1 contain similar amino acid sequences and may have originated from a common gene.
\end{abstract}

[Key Words: ATF; AP-1; transcription factors; gene family]

Received June 17, 1988; revised version accepted August 18, 1988.

Gene regulation in higher eukaryotes in many instances is controlled at the transcriptional level. Transcription of class II genes requires, in addition to RNA polymerase II, both general and promoter-specific transcription factors (Matsui et al. 1980; Samuels et al. 1982; Reinberg et al. 1987). The promoter-specific transcription factors function by binding to specific sequence elements within the promoter region. The mechanisms by which these factors stimulate transcription remains to be determined. The ability to purify these proteins by sequence-specific DNA affinity chromatography (Chodosh et al. 1986; Kadonaga and Tjian 1986; Rosenfeld and Kelly 1986) will facilitate addressing this issue.

We have been studying the cellular transcription factor(s) ATF, which has been implicated in the transcription of viral ElA- and cellular cAMP-inducible genes. An ATF consensus binding site, GTGACGT ${ }^{C}{ }_{A} A$ has been derived (Lin and Green 1988). The adenovirus E1A-inducible genes, E2, E3, and E4 contain one or more ATF binding sites in their promoters (Lee et al. 1987). Furthermore, a DNA fragment containing two ATF sites can confer (or increase) the ElA-inducibility onto a heterologous gene (Lee and Green 1987). In addition to E1A-inducible promoters, many cellular-inducible promoters contain ATF sites, which are required for cAMP inducibility. Moreover, multiple ATF sites can (at least in some instances) confer cAMP-inducibility onto heterologous genes (Montminy et al. 1986; Short et al. 1986; Lewis et al. 1987; Delegeane et al. 1987; Deutsch et al. 1987; Silver et al. 1987; Tsukada et al. 1987). Therefore, a common cis-acting element, the ATF-binding site, is involved in both E1A- and cAMP-inducible transcription.

Several observations suggest that a common protein binds to the ATF recognition site in E1A- and CAMP-inducible promoters. First, a $43-k D$ protein has been purified by sequence-specific DNA affinity chromatography using sequences from E1A-inducible viral (Hurst and Jones 1987) or cellular cAMP-inducible (Montminy and Bilezsikjian 1987; referred to as CREB) promoters. Second, by UV cross-linking, a common $45-\mathrm{kD}$ polypeptide has been shown to interact with the ATF sites in both E1A- and cAMP-inducible promoters (Lin and Green 1988). Taken together, these results suggest that a common $43-$ to $45-\mathrm{kD}$ polypeptide, ATF, is involved in the activation of two sets of genes that respond to different induction signals.

How E1A or cAMP affects ATF directly or indirectly remains to be determined. It has been suggested that the induction of transcription by cAMP involves phosphorylation of ATF by the cAMP-dependent protein kinase, protein kinase A (Montminy and Bilezsikjian 1987). We have purified ATF as a step toward understanding its regulation at the biochemical level. Contrary to previous reports (Hurst and Jones 1987; Montminy and Bilezsikjian 1987), our purification yields not a single protein but rather a series of polypeptides. We demonstrate that these polypeptides represent a family of proteins that are related by DNA binding specificity and by immunological cross-reactivity. This family of proteins includes the transcription factor AP- 1 , whose recognition sequence is similar but not identical to the ATF binding site. 


\section{Results}

\section{Purification of $A T F$}

In most of the experiments presented here, ATF was purified from JY cells, a human B cell lymphoma line. Similar results were obtained when HeLa cells were used (see, for example, Figs. 5 and $7 \mathrm{~B}$ and data not shown). A typical purification result is shown in Table 1 . This purification involves heat denaturation, phosphocellulose, DEAE-Sephacel column chromatography, and sequence-specific DNA affinity chromatography. Using this procedure, ATF was purified approximately 17,000fold (Table 1). As expected, the DNA affinity column is the most efficient step.

Consistent with our previous studies using the crude nuclear extract (Lee and Green 1987), purified ATF binds to a site directly upstream of the TATA box $(-50$ site $)$ and to two sites between -135 and -170 of the adenovirus E4 promoter (Fig. 1). ATF binds tightly to the DNA affinity column, remains bound at $0.3 \mathrm{M} \mathrm{KCl}$, and is eluted at $1.0 \mathrm{M} \mathrm{KCl}$. In contrast to ATF, two other DNA binding activities are eluted in the $0.3 \mathrm{M} \mathrm{KCl}$ wash step. One of these is a previously described activity (Lee and Green 1987) that protects the region around - 110 from DNase I digestion. The significance of this binding activity is unclear, because mutations at this site do not affect E4 transcription either in vitro or in vivo (Handa and Sharp 1984; Y.S. Lin, unpubl.). A second, previously undescribed activity binds to a site near -150 between the two upstream ATF sites. In the crude nuclear extract, this DNA binding activity could not be detected because its DNase I footprint is masked by the ATF DNase I footprints at the adjacent regions. We refer to the factor(s) responsible for this binding as E4F2. We have found that an eight-nucleotide sequence, GCACCCTT, is sufficient for specific binding of E4F2 and binding of E4F2 protects three guanosine residues within this sequence from methylation by dimethylsulfate as indicated in the diagram in Figure 1 (data not shown).

\section{Purified ATF is transcriptionally active}

The DNase I footprinting experiments confirm that the highly purified ATF retains sequence-specific DNA binding activity (Fig. 1). To test if the purified ATF is transcriptionally active, we depleted the crude HeLa cell

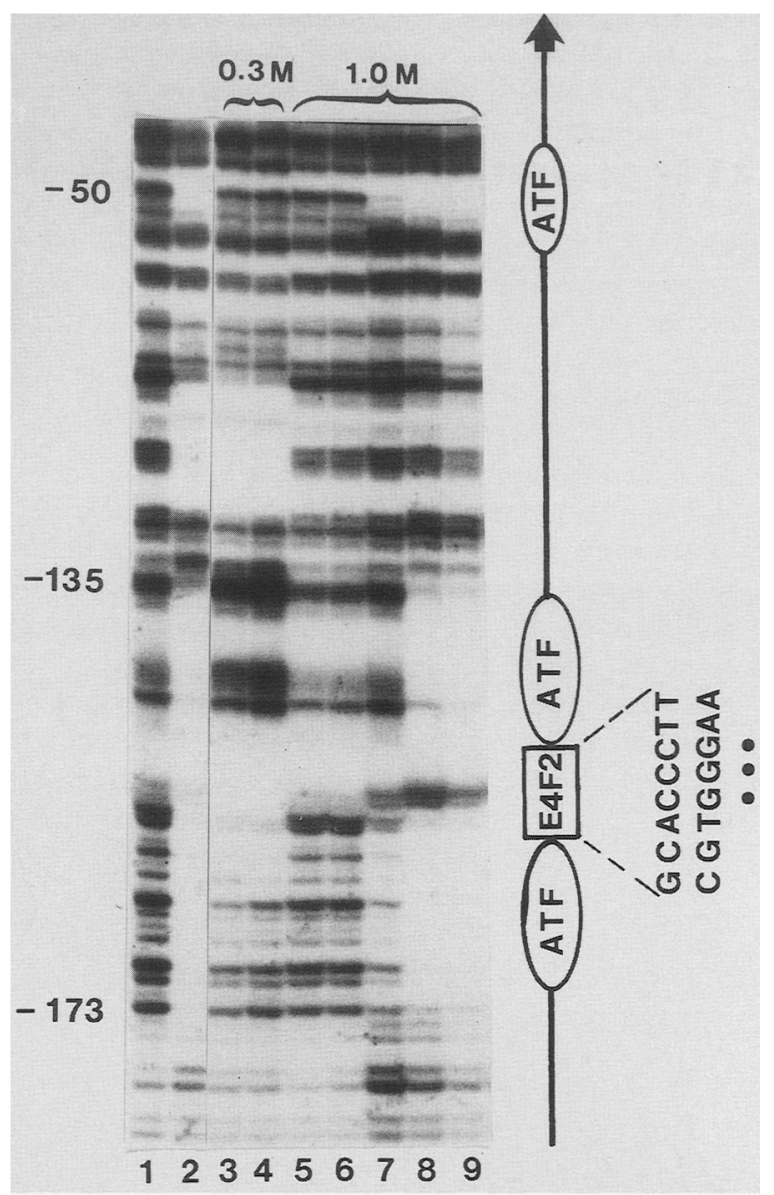

Figure 1. DNase I footprint analysis of the fractions from the ATF-specific DNA affinity column. A $3^{\prime}{ }^{\prime 32} \mathrm{P}$-end-labeled DNA fragment containing the adenovirus 5 E4 promoter region $(-240$ to +250$)$ was incubated with buffer D (lane 1), the phosphocellulose column $0.6 \mathrm{M}$ fraction (lane 2), or fractions from the ATF-specific DNA affinity column (lanes 3-9) followed by digestion with DNase I. Digested fragments were analyzed on a $10 \%$ sequencing gel. The salt $(\mathrm{KCl})$ concentrations used for elution from the ATF-specific DNA affinity column are indicated on top of the autoradiogram. Numbers on the left indicate the position within the E4 promoter. The diagram on the right indicates the binding of ATF and E4F2 on the E4 promoter. The eight nucleotide sequence that is sufficient for E4F2 binding is shown in the diagram and the guanosines that are projected from methylation by dimethylsulfate are indicated by closed circles.

Table 1. Purification of ATF

\begin{tabular}{lcccrr}
\hline Fraction & Protein $(\mathrm{mg})$ & Volume $(\mathrm{ml})$ & Units $^{\mathrm{a}}$ & Yield $(\%)$ & Relative purity \\
\hline Crude extract & 850 & 120 & 60,000 & 100 & 1 \\
Heat denaturation & 88 & 110 & 33,000 & 55 & 5 \\
Phosphocellulose & 8 & 15 & 15,000 & 25 & 27 \\
DEAE-Sephacel & 6 & 15 & 14,000 & 23 & 33 \\
DNA affinity & 0.0075 & 1.2 & 9,000 & 15 & 17,000
\end{tabular}

a One unit is defined as the amount of protein necessary to provide $100 \%$ protection in a DNase I footprint assay. 
nuclear extract of ATF by passing it over an ATF-specific DNA affinity column. This ATF-depleted nuclear extract does not support transcription of the $\mathrm{E} 4$ promoter. But the adenovirus major late promoter, which lacks an ATF site, is transcribed efficiently (Fig. 2, lane 1). E4 transcription is stimulated specifically by the addition of purified ATF (lanes 2 and 3). Therefore, the purified ATF maintains both sequence-specific DNA binding and transcriptional stimulatory activities.

\section{The ATF fraction contains two major proteins}

The polypeptides in the various fractions were analyzed by SDS - polyacrylamide gel electrophoresis followed by silver staining (Fig. 3). The final fraction from the DNA affinity column contains two predominant polypeptides of $43 \mathrm{kD}$ and $47 \mathrm{kD}$ (Fig. 3, lane 6). When analyzed on a gradient gel, the $43-\mathrm{kD}$ and $47-\mathrm{kD}$ polypeptides are each resolved into multiple, discrete bands (see below). For the convenience of discussion, we refer to the polypeptides in the $43-\mathrm{kD}$ or $47-\mathrm{kD}$ region collectively as the $43-\mathrm{kD}$ or $47-\mathrm{kD}$ protein. In addition, we consistently observe small amounts of polypeptides about $60 \mathrm{kD}$ and 39 $\mathrm{kD}$ in size (also see below and Discussion).

\section{Both $43-k D$ and $47-k D$ proteins purify in a sequence- specific manner}

As described above, previous studies have identified ATF as a 43-kD polypeptide (Hurst and Jones 1987; Montminy and Bilezsikjian 1987; Lin and Green 1988). We therefore considered the possibility that the $47-\mathrm{kD}$ protein is a contaminating, nonspecific DNA-binding protein. To test this possibility, we passed the phospho-

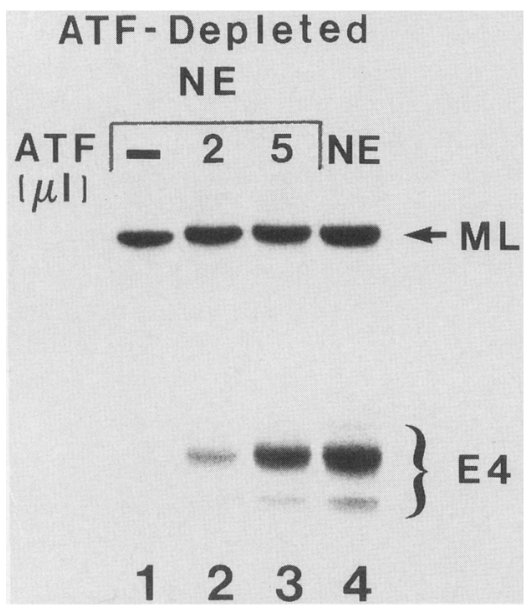

Figure 2. Purified ATF is transcriptionally active. Transcription of the adenovinus E4 and major late promoters was carried out either in an ATF-depleted HeLa nuclear extract (lanes 1-3) or in the crude nuclear extract (lane 4). The primer extension products representing the transcripts from major late (ML) or E4 (E4) promoters are indicated on the right. The transcription reaction was carried out either in the absence of added ATF (lanes 1 and 4) or with $2 \mu \mathrm{l}$ (lane 2) or with $5 \mu \mathrm{l}$ (lane 3) of purified ATF.

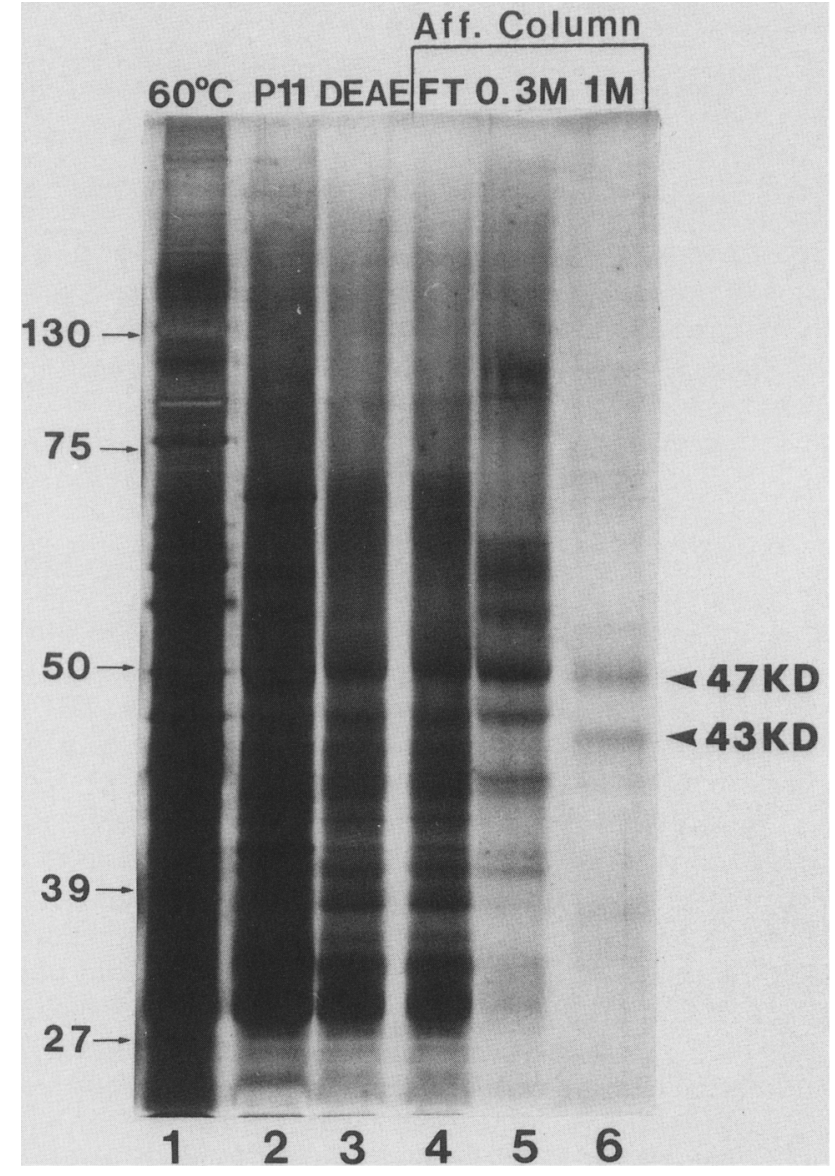

Figure 3. Identification of polypeptides in fractions from purification of ATF. The fractions generated during purification of ATF were subjected to electrophoresis on a $10 \%$ SDS-polyacrylamide gel and the polypeptides were detected by silver staining. The identity of each fraction is indicated on the top of each lane. Prestained protein molecular size markers from BioRad were analyzed in parallel and the molecular weights of the markers are indicated on the left. The markers are phosphorylase B $(130,000)$, bovine serum albumin $(75,000)$, ovalbumin $(50,000)$, carbonic anhydrase $(39,000)$, and soybean trypsin inhibitor $(27,000)$ from the top to the bottom. The major $43-\mathrm{kD}$ and $47-\mathrm{kD}$ polypeptides in the purified ATF preparation are indicated.

cellulose fraction through a nonspecific DNA column. All of the ATF-specific DNA binding activity eluted at $0.3 \mathrm{M} \mathrm{KCl}$ (data not shown), indicating that, as expected, ATF binds to the nonspecific DNA column with lower affinity than it does to the ATF-specific DNA affinity column. The $0.3 \mathrm{M} \mathrm{KCl}$ eluate from the nonspecific DNA column was adjusted to $0.1 \mathrm{M} \mathrm{KCl}$ and loaded onto an ATF-specific DNA affinity column. The $1.0 \mathrm{M} \mathrm{KCl}$ eluate from the ATF-specific DNA affinity column was then analyzed by SDS-polyacrylamide gel electrophoresis (Fig. 4). Significantly, both the $47-\mathrm{kD}$ and $43-\mathrm{kD}$ proteins are present in the $1.0 \mathrm{M} \mathrm{KCl}$ fraction from the ATF-specific DNA affinity column (lane 3). Thus, the $43-\mathrm{kD}$ and $47-\mathrm{kD}$ proteins behave identically: They elute at $0.3 \mathrm{M} \mathrm{KCl}$ from a nonspecific DNA column and at $1.0 \mathrm{M} \mathrm{KCl}$ from an ATF-specific DNA affinity column. 


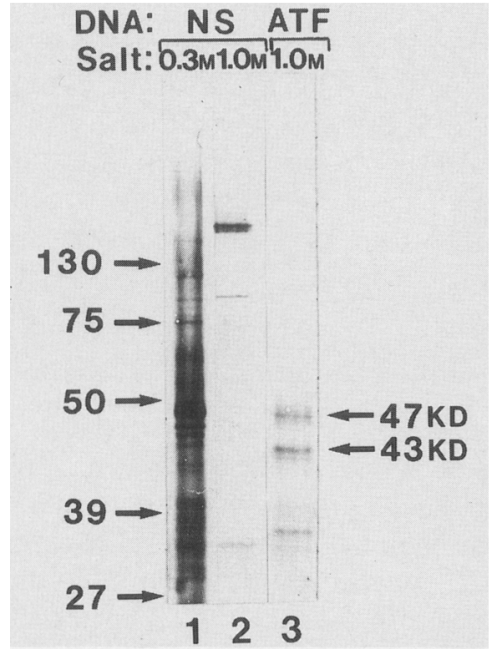

Figure 4. Analysis of the polypeptide composition of fractions from nonspecific and ATF-specific DNA affinity columns. An ATF-containing phosphocellulose fraction was loaded onto a nonspecific DNA column (containing the E4F2 oligonucleotide). The $0.3 \mathrm{M} \mathrm{KCl}$ eluate from the nonspecific DNA column was then subjected to chromatography on an ATF-specific DNA affinity column. The polypeptides in each fraction were detected by colloidal gold staining following transfer from a $10 \%$ SDS-polyacrylamide gel to Immobilon. The column and the salt used to generate each fraction is indicated above the lanes (NS, nonspecific). The positions of protein molecular weight markers are indicated on the left. The major $43-\mathrm{kD}$ and $47-\mathrm{kD}$ polypeptides in the purified ATF preparation are indicated on the right.

We conclude that the copurification of the $47-\mathrm{kD}$ protein is not due to nonspecific DNA binding. This conclusion is supported by the observation that following repeated passage over the ATF-specific DNA affinity column, the $43-\mathrm{kD}$ and $47-\mathrm{kD}$ proteins still copurify (data not shown). Furthermore, as shown below (Figs. 6 and 8 ) these proteins are antigenically related, strongly suggesting that the $47-\mathrm{kD}$ protein is not an unrelated, nonspecific DNA-binding protein.

\section{The 43-kD and 47-kD proteins are not generated by} proteolysis during purification

We then considered three possibilities for the relationship between these two proteins. First, the $43-\mathrm{kD}$ protein could be a proteolytic product of the $47-\mathrm{kD}$ protein (or both the $43-\mathrm{kD}$ and $47-\mathrm{kD}$ proteins could be proteolytic products of a larger protein). Second, the $47-\mathrm{kD}$ protein could be another form of ATF. For example, it may have different post-translational modifications than the $43-\mathrm{kD}$ protein (also see Discussion). Third, the $47-\mathrm{kD}$ protein could have a DNA binding specificity similar to but distinguishable from ATF. In this latter case, the $47-\mathrm{kD}$ protein could copurify with ATF by cross-reacting with the ATF site, which is present at high concentrations on the DNA affinity column.
To test for proteolysis during purification, we analyzed cell lysates by immunoblotting using an antiserum raised against the purified ATF fraction, which contains both $43-\mathrm{kD}$ and $47-\mathrm{kD}$ proteins (referred to as anti-43/47 antiserum). In lysed HeLa (Fig. 5, lane 1) and JY (Fig. 5, lane 2) cells, the major polypeptides that react with the antibody are $43 \mathrm{kD}$ and $47 \mathrm{kD}$. Because the major proteins in both HeLa and JY cells are the same size as those in the most purified fraction (Fig. 5, lane 3), we conclude that neither the $43-\mathrm{kD}$ nor the $47-\mathrm{kD}$ protein results from proteolysis during purification.

\section{The 43-kD and $47-k D$ proteins are immunologically related}

To ask if the $47-\mathrm{kD}$ protein is another form of ATF, we first examined whether the $43-\mathrm{kD}$ and $47-\mathrm{kD}$ proteins are immunologically related. Immunoblot analyses were performed using antisera raised against the gel-purified, individual proteins, referred to as anti-43 and anti-47 antisera, respectively (Fig. 6). The anti-43 antiserum reacts, as expected, with the $43-\mathrm{kD}$ protein, but also reacts with the $47-\mathrm{kD}$ protein (lane 1). Likewise, the anti-47 antiserum reacts with both $47-\mathrm{kD}$ and $43-\mathrm{kD}$ proteins (lane 2 ). Thus, the $43-\mathrm{kD}$ and $47-\mathrm{kD}$ proteins are immunologically related (also see Fig. 8).

\section{The 47-kD band contains both ATF and AP-1}

We next considered the possibility that the $47-\mathrm{kD}$ protein in the purified ATF preparation is the transcription factor AP-1. The AP-1 DNA binding site, GTGAGT ${ }_{A} A$ (Angel et al. 1987; Lee et al. 1987b), differs from the ATF consensus, GTGACGTC ${ }_{A} \mathrm{~A}$ (Lin and Green 1988), only by the absence of a single cytosine residue. In addition, in some studies AP-1 has been identified as a $47-\mathrm{kD}$

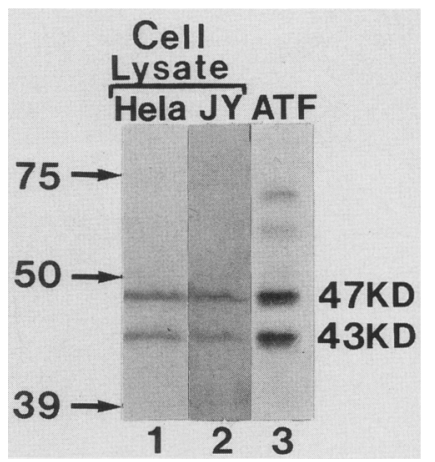

Figure 5. Immunoblot analysis of lysed JY and HeLa cells. About 1 to $2 \times 10^{7} \mathrm{HeLa}$ (lane 1) or JY (lane 2) cells were lysed by boiling for $5 \mathrm{~min}$ in SDS-containing sample loading buffer. The lysate was spun for $5 \mathrm{~min}$ to remove the debris, the supernatant was fractionated on a $10 \%$ SDS-polyacrylamide gel, and the polypeptides were detected by immunoblotting using the anti-43/47 antiserum (1:150 dilution). Purified ATF was analyzed in parallel (lane 3). The positions of protein molecular weight markers and the major $43-\mathrm{kD}$ and $47-\mathrm{kD}$ proteins are indicated. 


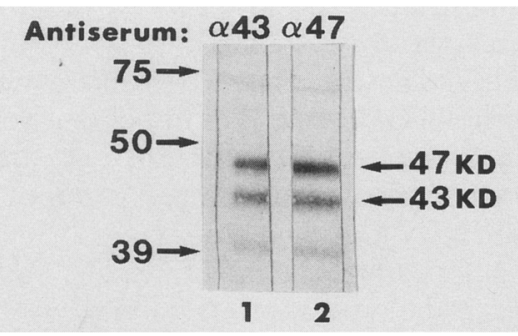

Figure 6. The $43-\mathrm{kD}$ and $47-\mathrm{kD}$ proteins are immunologically related. Aliquots of purified ATF were fractionated on a $10 \%$ SDS-polyacrylamide gel and analyzed by immunoblotting using either anti-43 (lane 1) or anti-47 (lane 2) antiserum (1:200 dilution). The positions of protein molecular weight markers and the major $43-\mathrm{kD}$ and $47-\mathrm{kD}$ proteins are indicated.

polypeptide (for example, see Bohmann et al. 1987). To determine the identity of the $47-\mathrm{kD}$ protein in our ATF preparation, we first performed immunoblot analysis using an AP-1-specific antibody (anti-pep 2). This antibody was raised against a synthetic peptide based on the cloned AP-1 sequence (v-iun, see Bohmann et al. 1987) and reacts specifically with a $47-\mathrm{kD}$ protein, AP-1 (Bohmann et al. 1987).

In this and the subsequent experiments in this report, the proteins were analyzed on gradient gels, which resolves both the $43-\mathrm{kD}$ and $47-\mathrm{kD}$ proteins into two bands. All four of these polypeptides are recognized by the anti-43/47 antiserum (Fig. 7A, lane M). We refer to them as the $43-\mathrm{kD}$ or $47-\mathrm{kD}$ upper band, and the $43-\mathrm{kD}$ or $47-\mathrm{kD}$ lower band. The upper band in each set appears as a doublet in some cases (see Figs. $7 \mathrm{C}$ and $8 \mathrm{~A}$ ).

Consistent with the previous report (Bohmann et al. 1987), the anti-pep 2 antibody reacts with a single band in a purified AP-1 preparation (see Materials and methods), the 47-kD lower band (Fig. 7A, lane 1). A band of identical size is also detected by the anti-pep 2 antibody in the purified ATF preparation (Fig. 7A, lane 2). Thus, the purified ATF preparation contains a small amount of AP-1. But the major form of the $47-\mathrm{kD}$ protein in the ATF preparation (the $47-\mathrm{kD}$ upper band) is not AP-1, because its electrophoretic mobility is clearly distinguishable from AP-1 and it does not react with the anti-pep 2 antibody.

\section{Evidence for multiple forms of ATF and AP-1}

Several observations suggest that the $47-\mathrm{kD}$ and $43-\mathrm{kD}$ upper bands are closely related, and that the $47-\mathrm{kD}$ and 43-kD lower bands are closely related. First, the lower bands are the major polypeptides following purification using an AP1-specific DNA affinity column, whereas the upper bands are the major polypeptides following purification using an ATF-specific DNA affinity column (Fig. 7B). Thus, the lower band in each set binds more strongly to an AP-1 site, whereas the upper band in each set binds more strongly to an ATF site. Second, the upper bands and the lower bands differ in their ability to function as substrates for cAMP-dependent protein kinase (protein kinase A). Identical amounts of the same ATF and AP-1 preparations used in Figure $7 \mathrm{~B}$ were added to an in vitro phosphorylation reaction using the catalytic subunit of protein kinase A (Fig. 7C). Both the $43-\mathrm{kD}$ and $47-\mathrm{kD}$ upper bands in the ATF preparation are phosphorylated by $\left[\gamma^{-32}\right.$ P]ATP and the catalytic subunit of protein kinase A in vitro. In contrast, neither lower band is phosphorylated (Fig. 7C, lane 1). The failure to phosphorylate the $43-\mathrm{kD}$ and $47-\mathrm{kD}$ lower bands is not due to their low abundance in the ATF preparation, because these bands are also not detectably phosphorylated in the AP-1 preparation (Fig. 7C, lane 2) in which they are present at high concentration (Fig. 7B,
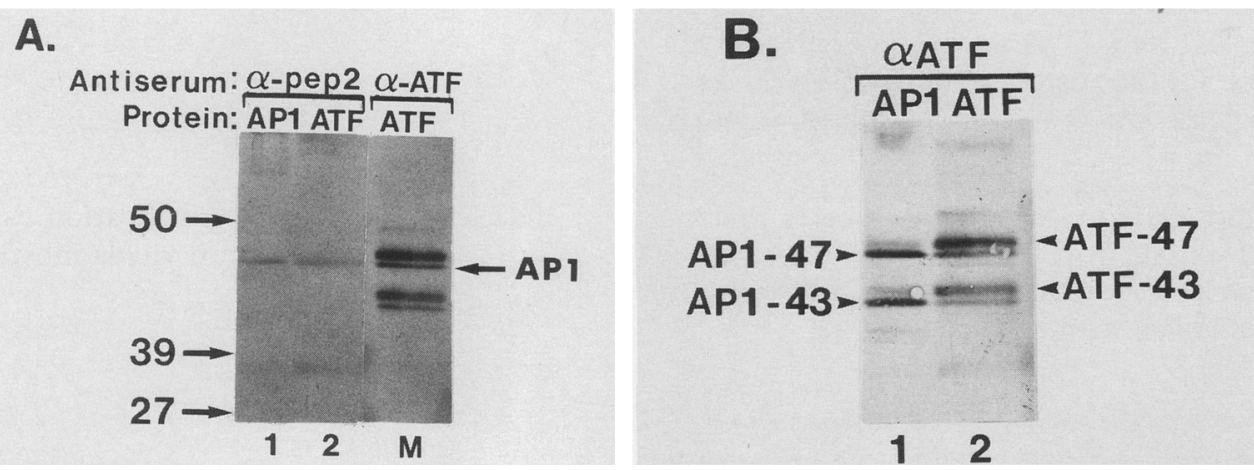

Figure 7. Evidence for multiple forms of ATF and AP-1. (A) The 47-kD lower band is AP-1. Aliquots of purified AP-1 (lane 1) and ATF (lane 2) were fractionated on a 7-13\% SDS-polyacrylamide gradient gel and analyzed by immunoblotting using the AP-1-specific anti-pep 2 antiserum (1:100 dilution). Purified ATF was analyzed in parallel and probed with the anti-43/47 (anti-ATF) antiserum (lane M). Prestained protein size markers were loaded between lane 2 and lane $M$ to provide alignment of the nitrocellulose strips after immunoblotting. The positions of protein molecular size markers are indicated on the left. $(B)$ The lower bands bind preferentially to an AP-1-specific DNA column and the upper bands bind preferentially to an ATF-specific DNA column. Aliquots of purified AP-1 (lane 1) and ATF (lane 2) were fractionated on a 7-13\% gradient gel and analyzed by immunoblotting using the anti-ATF antiserum (1:200 dilution). AP1-43, AP1-47, ATF-43, and ATF-47 are indicated by arrows. $(C)$ The upper bands in both sets are phosphorylated by protein kinase A. Aliquots of purified ATF (lane 1), AP-1 (lane 2), and a mixture of ATF and AP-1 (lane 3) were phosphorylated in vitro by protein kinase A and $\left[\gamma^{-32} \mathrm{P}\right] \mathrm{ATP}$ and analyzed on an $8-14 \%$ SDS-polyacrylamide gradient gel. The amounts of ATF and AP-1 used are the same as those used in $B$. (M) An immunoblot of purified ATF using the anti-43/47 (anti-ATF) antiserum (1:150 dilution). 
lane 1). Moreover, the AP-1 preparation does not contain an inhibitor of protein kinase $\mathrm{A}$, because mixing of equal amounts of the ATF and AP-1 preparations does not prevent phosphorylation of the upper bands in the ATF preparation (Fig. 7C, lane 3). Presumably, the upper bands in the AP-1 preparation are not detectably phosphorylated (Fig. 7C, lane 2) because of their relatively low abundance (Fig. 7B, lane 1). The result that AP-1 is not detectably phosphorylated by protein kinase $A$ in vitro is consistent with the fact that AP-1 (c-jun; Angel et al. 1988; Bohmann et al. 1988) lacks a protein kinase A consensus sequence (Arg-Arg-X-Ser-X; Edelman et al. 1987|. A previous study has also shown that ATF is a substrate for protein kinase A (referred to as CREB; Montminy and Bilezsikjian 1987).

Taken together, these results indicate tht the $43-\mathrm{kD}$ and $47-\mathrm{kD}$ upper bands are closely related, and likewise the $43-\mathrm{kD}$ and $47-\mathrm{kD}$ lower bands are closely related. The $47-\mathrm{kD}$ lower band is AP-1 as defined by its purification on an APl-specific DNA affinity column, its size, and its reactivity with the anti-pep 2 antiserum. Thus, it is likely that the $43-\mathrm{kD}$ lower band is another form of AP-1. For the convenience of discussion, we refer to the 43-kD and 47-kD lower bands as AP1-43 and AP1-47. Similarly, we refer to the $43-\mathrm{kD}$ and $47-\mathrm{kD}$ upper bands as ATF-43 and ATF-47 (see also Discussion).

\section{ATF and AP-1 are immunologically related}

The results in Figure 6 indicate that at least some of the $43-\mathrm{kD}$ polypeptides are immunologically related to at least some of the $47-\mathrm{kD}$ polypeptides. However, based solely upon these data, we cannot conclude that ATF (the upper bands) is immunologically related to AP-1 (the lower bands). To test this possibility, we performed immunoblot analysis using antiserum raised against the AP-1 DNA binding domain. A DNA segment encoding the carboxy-terminal 138 amino acids (the DNA binding domain) of AP-1 was fused in frame with Escherichia coli trpE gene (Angel et al. 1988). The fusion protein was isolated from $E$. coli and used to raise antibodies in rabbits (referred to as anti-c-jun antiserum; Chiu et al. 1988).

As expected, the anti-c-jun antiserum reacts with both AP1-43 and AP1-47 (Fig. 8A, lane 1). Significantly, this antiserum also reacts strongly with both ATF- 47 and ATF-43 (Fig. 8A, lane 1). Figure 8B demonstrates that the anti-c-jun antiserum is highly specific. In a relatively crude phosphocellulose fraction, which contains many polypeptides (Fig. 3, lane 2), the anti-c-jun antibody reacts with only one polypeptide (approximately $39 \mathrm{kD}$ ) in addition to the $43-\mathrm{kD}$ and $47-\mathrm{kD}$ proteins (Fig. 8B, lane 1 ). This $39-\mathrm{kD}$ polypeptide is removed during further purification (Fig. 8B, lane 2). This additional polypeptide may be the fos-associated protein (FAP) p39 which contains common tryptic peptides with AP-1 (Chiu et al. 1988; Rauscher et al. 1988b; see also Discussion). The specificity of this same anti-c-jun antiserum has been independently demonstrated in another study (Chiu et al. 1988). In that study the anti-c-jun antiserum was shown to react with only two proteins in a crude fraction, and did not react with the purified transcription factor AP-2 (Chiu et al. 1988).

Our results indicate that ATF and AP- 1 contain immunologically related DNA-binding domains. The fact that both the $43-\mathrm{kD}$ and $47-\mathrm{kD}$ forms of these proteins contain related DNA-binding domains strongly suggests that they can bind independently to DNA. This interpretation is consistent with the observation that the ATF-specific DNA binding activity sediments in a glycerol gradient at $\sim 3 S$ (data not shown). For a spherical protein with average hydration and partial-specific volumes, this value corresponds to a molecular weight of 40-45,000 (Cantor and Schimmel 1980). The similarity between this estimate of native molecular weight and the denatured molecular weights of the proteins on an SDS-polyacrylamide gel suggests that these polypeptides are not associated by protein-protein interactions.

\section{Discussion}

In this report we have purified the transcription factor ATF using sequence-specific DNA affinity chromatography. Surprisingly, the purification yields not a single polypeptide but rather a series of polypeptides. Our results suggest that these polypeptides represent multiple forms of two different transcription factors: ATF and AP-1. The properties of the purified polypeptides are summarized in Table 2 and discussed below.

\section{$A T F$ and $A P-1$ are distinct transcription factors}

ATF and AP-1 are transcription factors that were first identified from studies using different promoters. The binding sites of these two proteins are similar but nonidentical. The consensus binding site for ATF is GTGACGTC ${ }_{\mathrm{A}} \mathrm{A}$ (Lin and Green 1988), whereas the AP-1 consensus sequence is GTGAGT ${ }_{\mathrm{A}} \mathrm{A}$ (Angel et al. 1987; Bohmann et al. 1987; Lee et al. 1987b).

Several experimental observations indicate that ATF and AP-1 are different factors. First, each protein binds more strongly to its cognate than to the heterologous site. For example, purification using an ATF-specific DNA affinity column yields predominantly ATF proteins (Fig. 7B). Whereas, purification using an AP1-specific DNA affinity column yields mostly AP-1 proteins (Fig. 7B). Furthermore, the DNase I footprint of an ATF site is competed more efficiently by a DNA fragment containing an ATF site than by one containing an AP-1 site (Lee and Green 1987; unpubl.). Consistent with this result, in a converse experiment, a fusion protein containing an AP-1 DNA binding domain (trpE-c-jun fusion protein isolated from $E$. coli) binds more efficiently to an AP-1 site than to an ATF site (Angel et al. 1988; K. Hattori, P. Angel, and M. Karin, unpubl.). Second, the electrophoretic mobilities of DNA-protein complexes formed using ATF and AP-1 sites are different (Hurst and Jones 1987). Third, as shown here, ATF and AP-1 have distinguishable electrophoretic mobilities (Fig. 7), different reactivities toward the anti-pep 2 antiserum (Fig. 7A), and different abilities to be phosphorylated by protein kinase A (Fig. 7C). Fourth, ATF and AP-1 appear to 


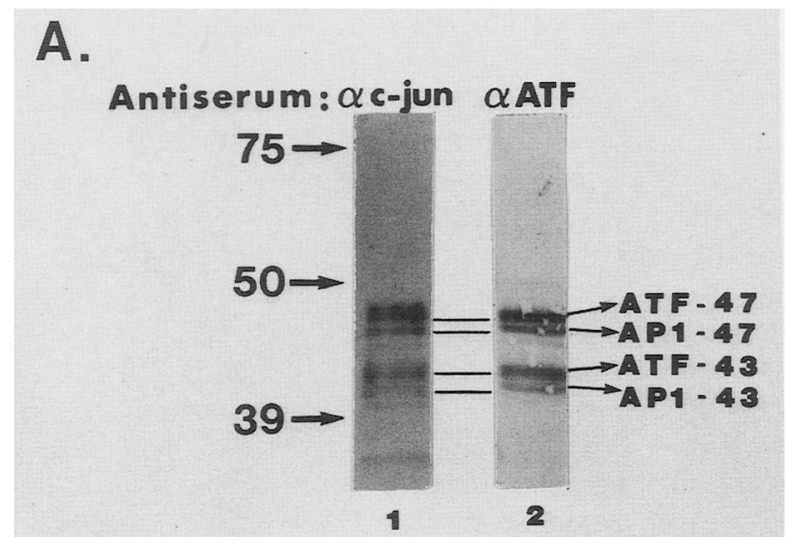

Figure 8. ATF and AP-1 are immunologically related. $(A)$ Anti-c-jun antiserum reacts with both forms of ATF. Purified ATF was fractionated on an $8-14 \%$ SDS-polyacrylamide gradient gel and analyzed by immunoblotting using an antiserum against the DNA binding domain of AP-1 (anti-c-jun antiserum $1: 1500$ dilution, lane 1). Lane 2 shows an immunoblot of purified ATF from a $7-13 \%$ SDS-polyacrylamide gradient gel using anti-43/47 antiserum (1:150 dilution). The identity of each polypeptide is indicated on the right. $(B)$ The anti-c-jun antiserum has high specificity. An aliquot of proteins from the phosphocellulose column (lane 1) or from the ATF-DNA affinity column (lane 2) was fractionated on a $10 \%$ SDS-polyacrylamide gel and analyzed by immunoblotting using the antic-jun antiserum (1 : 1000 dilution). The $43-\mathrm{kD}$ and $47-\mathrm{kD}$ proteins are indicated.

mediate distinct transcriptional regulatory responses. For example, multiple ATF sites can (at least in some instances) confer cAMP-inducibility onto heterologous genes (Montminy et al. 1986; Short et al. 1986; Delegeane et al. 1987; Deutsch et al. 1987; Lewis et al. 1987; Silver et al. 1987; Tsukada et al. 1987), whereas multiple AP-1 sites do not (Imagawa et al. 1987).

Although ATF and AP-1 are distinct transcription factors, they have a number of features in common. First, their DNA-binding sites are similar. Second, both are relatively heat stable and their chromatographic

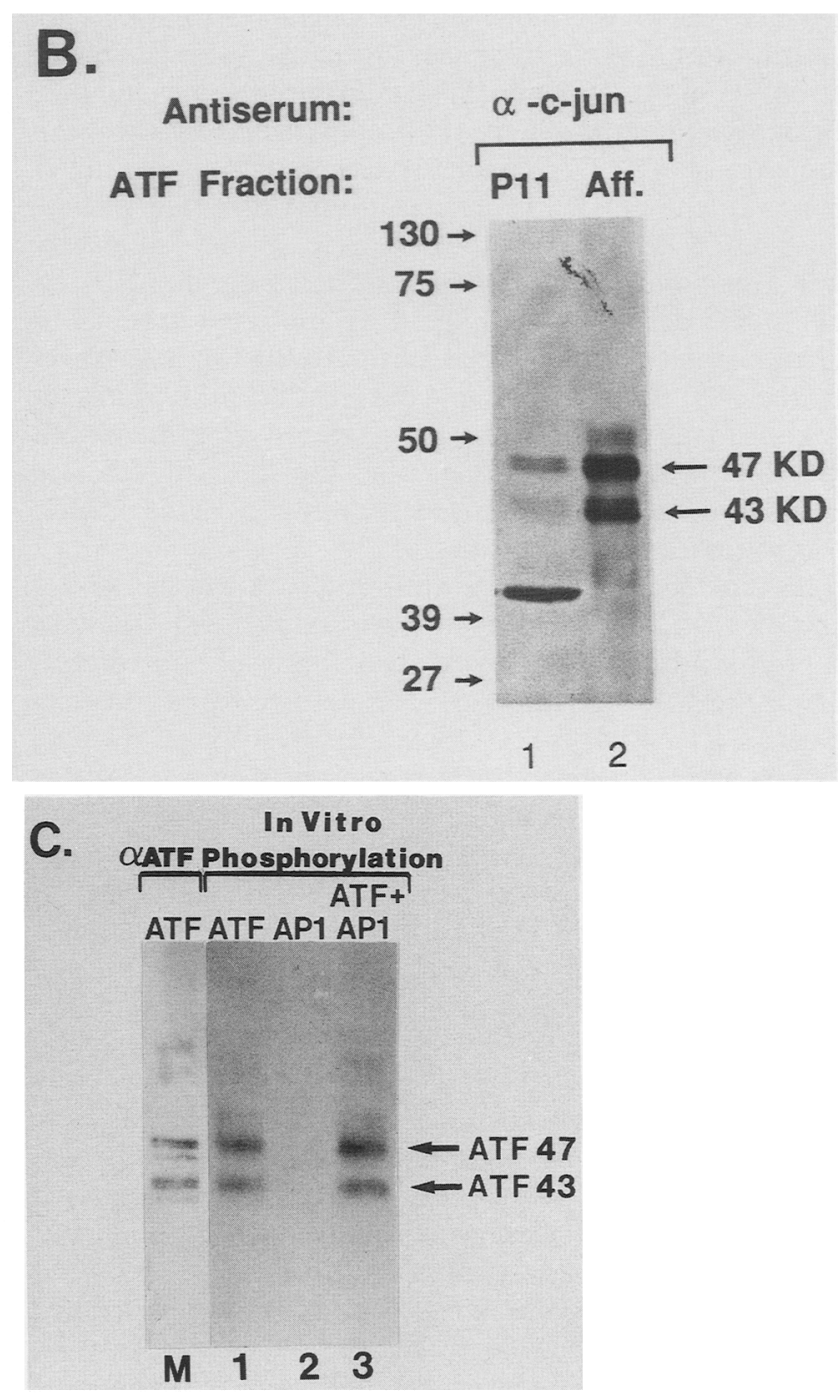

properties are similar (see Materials and methods and Results). Third, there are multiple forms of both ATF and AP-1. Fourth, ATF and AP-1 are immunologically related, suggesting that they contain similar amino acid sequences.

\section{Multiple forms of ATF and AP-1}

We have found that four major polypeptides copurify from an ATF-specific DNA affinity column. Based upon

Table 2. Properties of ATF and AP-1 proteins

\begin{tabular}{lcccccc}
\hline Proteins & $\begin{array}{l}\text { Affinity for } \\
\text { AP-1 site }\end{array}$ & $\begin{array}{l}\text { Affinity for } \\
\text { ATF site }\end{array}$ & $\begin{array}{l}\text { Phosphorylation } \\
\text { by protein } \\
\text { kinase A }\end{array}$ & $\begin{array}{l}\text { Reactivity to } \\
\text { anti-pep 2 } \\
\text { antiserum }\end{array}$ & $\begin{array}{l}\text { Reactivity to } \\
\text { anti-c-jun } \\
\text { antiserum }\end{array}$ & $\begin{array}{l}\text { Reactivity to } \\
\text { anti-43/47 } \\
\text { antiserum }\end{array}$ \\
\hline ATF-47 & W & S & W & - & + & + \\
AP1-47 & S & W & S & + & - & + \\
ATF-43 & S & W & - & - & + \\
AP1-43 & S & & - & + & + \\
\hline
\end{tabular}

(S) strong; (W) weak. 
several criteria (see Results), we refer to them as ATF-43, ATF-47, AP1-43, and AP1-47. However, it is conceivable that the precise DNA-binding specificity of some of these polypeptides can be distinguishable from both ATF and AP-1. Further experiments will be required to determine the DNA binding specificity of each polypeptide.

In previous studies ATF has been identified as a single 43- to 45-kD polypeptide (Hurst and Jones 1987; Montminy and Bilezsikjian 1987; Lin and Green 1988). In this report, we present evidence for an additional form of ATF (ATF-47), which is present in both JY and HeLa cells (Figs. 5 and 7) in approximately equal abundance to the previously identified form of ATF (ATF-43). ATF binding sites are found in both CAMP- and E1A-inducible promoters (Lin and Green 1988 and references therein). Perhaps the different forms of ATF mediate these distinct transcriptional regulatory responses. The failure to detect ATF-47 previously may be because this protein is not efficiently extracted from nuclei during the standard preparation of nuclear extracts (Dignam et al. 1983). We have modified the standard nuclear extract procedure to prepare extracts from JY cells and this may account for our ability to detect ATF-47. Similar to the case of ATF, we also present evidence for a new form of AP-1 (APl-43) which is distinguishable from the previously defined AP-1 (AP1-47; Angel et al. 1987; Lee et al. $1987 \mathrm{~b})$.

It is interesting that the electrophoretic mobility difference between the two forms of ATF is similar to that between the two forms of AP-1 (Fig. 7). Thus, the different ATF and AP-1 proteins may be generated by a similar mechanism, such as alternative splicing or posttranslational modification. Alternatively, each ATF and AP-1 polypeptide may be encoded by a separate gene. Any of these possibilities could explain the reactivity of the anti-pep 2 antiserum with AP1-47 but not with AP1-43 (Fig. 7A).

There are now several well-documented examples of different transcription factors with similar or identical DNA-binding specificity. In addition to the multiple forms of ATF and AP-1 described in this report, other examples include the octamer-binding protein (Staudt et al. 1986; Fletcher et al. 1987; Scheidereit et al. 1987), CCAAT box-binding protein (Dorn et al. 1987; Raymondjean et al. 1988), and NFkB (Baldwin and Sharp 1988). The fact that more than one protein can bind to the same DNA site means that DNA-binding specificity cannot be used as the sole criterion to define a sequencespecific DNA binding protein. Likewise, sequence-specific DNA-affinity chromatography also cannot be used as a stringent criterion of protein identity.

\section{ATF and AP-1 are members of a family of immunologically related transcription factors}

Although ATF and AP-1 are different proteins, they are antigenetically related. Recent studies have shown that AP-1 is probably encoded by the proto-oncogene c-jun (Bohmann et al. 1987; Angel et al. 1988). A family of
AP-1 related proteins has been postulated based on the detection of multiple bands when c-jun is used to probe a genomic Southern blot (Bohmann et al. 1987; Angel et al. 1988). In this report, we demonstrate the existence of an ATF/AP-1 multiprotein family based upon the presence of at least three polypeptides that are antigenetically related to AP-1 (AP1-47). The steroid hormone receptors are another example of a family of transcription factors (Petkovich et al. 1987; for reviews, see Yamamoto 1985; Green and Chambon 1986; Green et al. 19871 .

Whether there are other proteins that belong to the ATF/AP-1 family remains to be determined. It has been recently shown that the human c-fos protein is present in DNA-protein complexes formed using an AP-1 site (Franza et al. 1988; Rauscher et al. 1988a). Human c-fos protein is heterogenous, about $55-60 \mathrm{kD}$ in size (Curran et al. 1984) and our purified ATF and AP-1 preparations contain minor proteins in this size range. It will be interesting to determine if these minor polypeptides are c-fos proteins, and if c-fos proteins are immunologically related to ATF and AP-1. The purified ATF and AP-1 preparations also contain variable amounts of a $39-\mathrm{kD}$ protein. This $39-\mathrm{kD}$ protein may be the fos-associated proteins (FAP) p39 described previously (Curran and Teich 1982; Curran et al. 1985). AP-1 and p39 contain common tryptic peptides (Chiu et al. 1988; Rauscher et al. 1988b), although the relationship between AP-1 and p39 is not clear. Another possible member of this ATF/AP-1 multi-gene family is jun-B, which has homology to the DNA binding domain of v-jun (Ryder et al. 1988).

Some epitopes shared by ATF and AP-1 are in the DNA-binding domain, because the AP1-specific antiserum used (anti-c-jun antiserum) was directed against this region (Fig. 8). Delineating the similarities and differences between the DNA-binding regions of ATF and AP-1 should enable us to understand their altered DNAbinding specificities. It will also be interesting to know how ATF and AP-1 are different in other regions, which may account for their distinct transcriptional regulatory activities.

The immunological cross-reactivity and similar DNA-binding specificity, in conjunction with our other results, strongly suggests that ATF and AP-1 contain similar amino acid sequences and may have originated from a common gene. However, proof of this point must await cloning of the genes that encode these polypeptides. Consistent with the possibility that ATF and AP-1 arose from a common primordial gene, activities similar to ATF and AP- 1 are found in lower eukaryotes. For example, several proteins with AP1-like DNA-binding specificity have been identified in Saccharomyces cerevisiae and Schizosaccharomyces pombe (Harshman et al. 1988; Jones et al. 1988). Likewise, we have found that the yeast $S$. cerevisiae contains a transcriptional-activating protein with identical DNA-binding specificity to mammalian ATF (Y.S. Lin and M.R. Green, in prep.). Whether all of these yeast and mammalian proteins are related at the amino acid level remains to be determined. 


\section{Materials and methods}

\section{Purification of ATF}

HeLa cell nuclear extract was prepared according to the published procedure of Dignam et al. (1983). JY cell extracts were prepared from either fresh or frozen nuclei. Nuclei were suspended in one-half to one volume of buffer containing $20 \mathrm{mM}$ HEPES- $\mathrm{KOH}$ (pH 7.9), $0.42 \mathrm{M} \mathrm{NaCl}, 1.5 \mathrm{~mm} \mathrm{MgCl}_{2}, 0.2 \mathrm{~mm}$ EDTA, $0.25 \mathrm{mM}$ DTT, $0.5 \mathrm{~mm}$ PMSF, and $10 \%$ glycerol. The final $\mathrm{NaCl}$ concentration was adjusted to $0.34 \mathrm{M}$ and the suspension was stirred gently at $4^{\circ} \mathrm{C}$ for $1 \mathrm{hr}$. The solution was passed through multiple layers of cheesecloth and the nuclei were washed one more time with one-quarter volume of the same buffer. Extracts were pooled, and spun at $16,000 g_{\text {av }}$ for 30 min to pellet debris. Proteins in the supernatant were precipitated by addition of ammonium sulfate to $70 \%$ and the ammonium sulfate pellet was collected and resuspended in an appropriate volume of buffer D (Dignam et al. 1983) and dialyzed against buffer D overnight.

Typically, ATF was prepared from extract containing $800-1000 \mathrm{mg}$ of total proteins as follows. The extract was heated at $60^{\circ} \mathrm{C}$ for $5 \mathrm{~min}$ and pelleted at $15,000 \mathrm{~g}_{\mathrm{av}}$ for $30 \mathrm{~min}$ at $4^{\circ} \mathrm{C}$ to remove denatured proteins. The supernatant was loaded onto a phosphocellulose column (Whatman). The column was prepared according to the manufacturer's instructions, washed with 3 column volumes of buffer D containing $200 \mu \mathrm{g} / \mathrm{ml} \mathrm{BSA}$ (bovine serum albumin), and equilibrated in buffer $D$ before use. The extract was loaded onto the phosphocellulose column at 4-6 mg protein per $\mathrm{ml}$ of resin, at a flow rate of 5-10 $\mathrm{ml} / \mathrm{cm}^{2} \cdot \mathrm{hr}$. After loading, the column was washed with one column volume of buffer $\mathrm{D}$ and 6 column volumes of buffer $\mathrm{D}$ containing $0.25 \mathrm{M} \mathrm{KCl}$ before ATF was eluted with 3 column volumes of buffer $\mathrm{D}$ containing $0.6 \mathrm{M} \mathrm{KCl}$. This $0.6 \mathrm{M} \mathrm{KCl}$ fraction was dialyzed against buffer $\mathrm{D}$ overnight and loaded onto a DEAE-Sephacel (Pharmacia) column equilibrated in buffer $D$. The flowthrough and the $0.25 \mathrm{M} \mathrm{KCl}$ fractions from the DEAESephacel column were pooled and dialyzed to bring the salt concentration to $0.1 \mathrm{M} \mathrm{KCl}$ before it was loaded onto an ATFspecific DNA affinity column. We have found that elimination of the DEAE-Sephacel step does not affect the purity of the final fraction. Consequently, this step was eliminated in the later experiments.

The ATF-specific DNA affinity column was prepared by coupling ligated ATF-specific oligonucleotides to CNBR-activated Sepharose 4B (Pharmacia) according to Kadonaga and Tjian (1986). The column was equilibrated in buffer D containing $0.1 \%$ NP- 40 prior to loading. It was then washed with 3 column volumes of buffer D containing $0.1 \% \mathrm{NP}-40$ and 10 column volumes of buffer D containing $0.3 \mathrm{M} \mathrm{KCl}$ and $0.1 \% \mathrm{NP}-40$. ATF was eluted from the column with buffer D containing $1.0 \mathrm{M}$ $\mathrm{KCl}$ and $0.1 \% \mathrm{NP}-40$.

\section{Preparation of $A P-1$}

AP-1 was purified from HeLa cells according to Angel et al. (1987).

\section{Preparation of ATF-depleted extracts}

Crude HeLa cell nuclear extract $(1 \mathrm{ml})$ was passed over a $0.2 \mathrm{ml}$ ATF-specific DNA affinity column equilibrated with buffer D containing $10 \mathrm{~mm}$ EDTA. The $10 \mathrm{~mm}$ EDTA prevents nuclease digestion of the immobilized DNA. The column was washed with 2 column volumes of buffer D containing $0.3 \mathrm{M} \mathrm{KCl}$ and $10 \mathrm{~mm}$ EDTA. The flowthrough and the $0.3 \mathrm{M} \mathrm{KCl}$ fractions were pooled and dialyzed against buffer $\mathrm{D}$. The dialyzed solu- tion was concentrated to $1 \mathrm{ml}$ using Centricon microconcentrators (Amicon).

\section{DNase I, dimethylsulfate footprint analyses, and in vitro transcription assay}

These assays were performed according to procedures described previously by Lee and Green (1987) and Lee et al. (1987a).

\section{Glycerol gradient sedimentation analysis}

Two hundred and fifty DNase I footprinting units of ATF in 100 $\mu l$ were sedimented through a $1-\mathrm{ml} 10-30 \%$ glycerol gradient [containing $20 \mathrm{~mm}$ HEPES-KOH $(\mathrm{pH} 7.9$ ), $0.2 \mathrm{~mm}$ DTT, $100 \mathrm{~mm}$ $\mathrm{KCl}, 0.5 \mathrm{~mm}$ PMSF] at $50,000 \mathrm{rpm}$ for $18 \mathrm{hr}$ at $4^{\circ} \mathrm{C}$ in a Beckman TLS-55 rotor. The ATF fraction used in this experiment was prepared by fractionating the heat-denatured HeLa cell nuclear extract on an ATF-specific DNA affinity column directly without the phosphocellulose column step. Fractions $(100 \mu \mathrm{l})$ were collected from the top and analyzed.

\section{Detection of proteins by staining or immunoblotting}

Aliquots of proteins were boiled for $3 \mathrm{~min}$ and loaded onto either a $10 \%$ SDS-polyacrylamide gel or a $7-13 \%$ (or $8-14 \%$ ) SDS-polyacrylamide gradient gel. After electrophoresis, proteins were detected by either staining or immunoblotting. For silver staining, the gel was treated according to published procedure (Nielsen and Brown 1984). For colloidal gold staining, proteins were electrophoretically transferred to a piece of Immobilon paper (Millipore) and stained by Auro-Dye forte (Jassen Life Sciences/ colloidal gold according to the manufacturer's instructions. For immunoblotting, proteins were electrophoretically transferred to a piece of nitrocellulose paper /Schleicher and Schuelly. The paper was then blocked with solution containing $20 \mathrm{~mm}$ Tris- $\mathrm{HCl}(\mathrm{pH} 7.4), 0.9 \% \mathrm{NaCl}, 0.05 \%$ Tween-20, $0.001 \%$ antifoam $\mathrm{A}$, and $5 \%$ nonfat-dried milk followed by incubation with the appropriate antiserum at room temperature overnight as indicated. The filter was then washed and incubated with either anti-mouse or anti-rabbit alkaline phosphatase-conjugated antibody (Promega). The blocking and washing steps were carried out according to Burnette (1981). The enzymatic color reaction was carried out according to the manufacturer's instructions.

\section{Immunization of mice by nitrocellulose filter implantation}

The procedure used was a modified version of a method communicated by Dr. Susan Dutcher. Protein (100-200 ng) was either spotted directly onto a nitrocellulose filter or transferred from a gel to the filter. The nitrocellulose filter either contained a mixture of the $43-\mathrm{kD}$ and the $47-\mathrm{kD}$ proteins or contained the individual $43-\mathrm{kD}$ or $47-\mathrm{kD}$ protein separated on an SDS-polyacrylamide gel. The filter was then implanted subdermally on the back of the neck of a 2- to 7-month-old female BALB/c mouse. Five weeks later, blood was collected by tail bleeding and the presence of antibody against ATF was determined by immunoblot analysis.

\section{Acknowledgments}

We gratefully acknowledge T. Bos and P. Vogt for their generous gift of the anti-pep 2 antiserum and Jennifer A. Meek for the anti-c-jun antiserum. We thank D. Wiley for providing IY cell nuclei, B. Coukos for assistance with the nitrocellulose im- 
plantation procedure, and S. Dutcher for communicating the nitrocellulose implantation method. The excellent technical assistance of M. McCaffrey is gratefully acknowledged. T. Hai was supported by a National Institutes of Health postdoctoral fellowship. This work was supported by grants from the $\mathrm{Na}$ tional Institutes of Health and from The Chicago Community/ Searle Scholars Program to M.R.G.

\section{References}

Angel, P., M. Imagawa, R. Chiu, B. Stein, R.J. Imbra, H.J. Tahmsdorf, C. Jonat, P. Herrlich, and M. Karin. 1987. Phorbol ester-inducible genes contain a common cis element recognized by a TPA-modulated trans-acting factor. Cell 49: 729-739.

Angel, P., E.A. Allegretto, S.T. Okino, K. Hattori, W.J. Boyle, T. Hunter, and M. Karin. 1988. Oncogene jun encodes a sequence-specific trans-activator similar to AP-1. Nature 332: $166-171$.

Baldwin, A.S. and P.A. Sharp. 1988. Two transcription factors, NF-kB and $\mathrm{H} 2 \mathrm{TFl}$, interact with a single regulatory sequence in the class I major histocompatibility complex promoter. Proc. Natl. Acad. Sci. 85: 723-727.

Bohmann, D., T.J. Bos, A. Admon, T. Nishimura, P.K. Vogt, and R. Tjian. 1987. Human proto-oncogene c-jun encodes a DNA binding protein with structural and functional properties of transcription factor AP-1. Science 238: 1386-1392.

Burnette, W.N. 1981. 'Western blotting': Electrophoretic transfer of proteins from sodium dodecyl sulfate-polyacrylamide gels to unmodified nitrocellulose and radiographic detection with antibody and radioiodinated protein A. Anal. Biochem. 112: 195-203.

Cantor, C.R. and P.R. Schimmel. 1980. Biophysical chemistry. W.H. Freeman and Co., San Francisco, California.

Chiu, R., W.J. Boyle, J. Meek, T. Smeal, T. Hunter, and M. Karin. 1988. The c-fos protein interacts with c-jun/AP-1 to stimulate transcription of AP-1 responsive genes. Cell 54: $541-552$.

Chodosh, L.A., R.W. Carthew, and P.A. Sharp. 1986. A single polypeptide possesses the binding and transcription activities of the adenovirus major late transcription factor. Mol. Cell. Biol. 6: 4723-4733.

Curran, T. and N.M. Teich. 1982. Identification of 39,000 dalton protein in cells transformed by FBJ murine osteosarcoma virus. Virology 116: 221-235.

Curran, T., C. Van Beveren, N. Ling, and I.M. Verma. 1985. Viral and cellular fos proteins are complexed with a 39,000 dalton cellular protein. Mol. Cell. Biol. 5: 167-172.

Delegeane, A.M., L.H. Ferland, and P.L. Mellon. 1987. Tissuespecific enhancer of the human glycoprotein hormone $\alpha$ subunit gene: dependence on cyclic AMP-inducible elements. Mol. Cell. Biol. 7: 3994-4002.

Deutsch, P.J., J.L. Jameson, and J.F. Habener. 1987. Cyclic AMP responsiveness of human gonadotropin- $\alpha$ gene transcription is directed by a repeated 18-base pair enhancer. J. Biol. Chem. 262: 12169-12174.

Dignam, J.D., R.M. Lebovitz, and R.G. Roeder. 1983. Accurate transcription initiation by RNA polymerase II in a soluble extract from isolated mammalian nuclei. Nucleic Acids Res. 11: $1475-1489$.

Dorn, A., J. Bollekens, A. Staub, C. Benoist, and D. Mathis. 1987. A multiplicity of CCAAT box-binding proteins. Cell 50: $863-872$

Edelman, A.M., D.K. Blumenthal, and E.G. Krebs. 1987. Protein serine/threonine kinase. Annu. Rev. Biochem. 56: 567-613.
Fletcher, C., N. Heintz, and R.G. Roeder. 1987. Purification and characterization of OTF-1, a transcription factor regulating cell cycle expression of a human histone $\mathrm{H} 2 \mathrm{~b}$ gene. Cell 51: 773-781.

Franza, B.R., Jr., F.J. Rauscher III, S.F. Josephs, and T. Curran. 1988. The fos complex and fos-related antigens recognize sequence elements that contain AP-1 binding sites. Science 239: 1150-1153.

Green, S. and P. Chambon. 1986. A superfamily of potentially oncogenic hormone receptors. Nature 324: 615-617.

Green, S., H. Gronemeyer, and P. Chambon. 1987. Structure and function of steroid hormone receptors. In Growth factors and oncogenes in breast cancer (ed. M. Sluyser), pp. 7-28. Ellis Horwood Ltd., England.

Handa, H. and P.A. Sharp. 1984. Requirement for distal upstream sequences for maximal transcription in vitro of early region IV of adenovirus. Mol. Cell Biol. 4: 791-798.

Harshman, K.D., W.S. Moye-Rowley, and C. Parker. 1988. Transcriptional activation by the SV40 AP-1 recognition element in yeast is mediated by a factor similar to AP- 1 that is distinct from GCN4. Cell 53: 321-330.

Hurst, H.C. and N. Jones. 1987. Identification of factors that interact with the Ela-inducible adenovirus E3 promoter. Genes Dev. 1: 1132-1146.

Imagawa, M., R. Chiu, and M. Karin. 1987. Transcription factor AP-2 mediate induction by two different pathways: protein kinase $C$ and cAMP. Cell 51: 251-260.

Jones, R.H., S. Moreno, P. Nurse, and N.C. Jones. 1988. Expression of the SV40 promoter in fission yeast: Identification and characterization of an AP1-like factor. Cell 53: 659667.

Kadonaga, J.T. and R. Tjian. 1986. Affinity purification of sequence-specific DNA binding proteins. Proc. Natl. Acad. Sci. 83: 5889-5893.

Lee, K.A.W. and M.R. Green. 1987. A cellular transcription factor E4Fl interacts with an E1A-inducible enhancer and mediates constitutive enhancer function in vitro. EMBO J. 6: $1345-1353$.

Lee, K.A.W., T.Y. Hai, L. SivaRaman, B. Thimmappaya, H.C. Hurst, N.C. Jones, and M.R. Green. 1987a. A cellular protein activating transcription factor, activates transcription of multiple Ela-inducible adenovirus early promoters. Proc. Natl. Acad. Sci. 84: 8355-8359.

Lee, W., P. Mitchell, and R. Tjian. 1987b. Purified transcription factor AP-1 interacts with TPA-inducible enhancer elements. Cell 49: 741-752.

Lewis, E.J., C.A. Harrington, and D.M. Chikaraishi. 1987. Transcriptional regulation of the tyrosine hydroxylase gene by glucocorticoid and cyclic AMP. Proc. Natl. Acad. Sci. 84: $3550-3554$.

Lin, Y.S. and M.R. Green. 1988. Interaction of a common transcription factor, ATF, with regulatory elements in both E1aand cyclic AMP-inducible promoters. Proc. Natl. Acad. Sci. 85: 3396-3400.

Matsui, T., J. Segall, P.A. Weil, and R.G. Roeder. 1980. Multiple factors required for accurate initiation of transcription by purified RNA polymerase II. I. Biol. Chem. 255: 1199211996.

Montminy, M.R., K.A. Sevarino, J.A. Wagner, G. Mandel, and R.H. Goodman. 1986. Identification of a cyclic-AMP-responsive element within the rat somatostatin gene. Proc. Natl. Acad. Sci. 83: 6682-6686.

Montminy, M.R. and L.M. Bilezsikjian. 1987. Binding of a nuclear protein to the cyclic AMP response element of the somatostatin gene. Nature 328: $175-178$.

Nielsen, B.L. and L.R. Brown. 1984. The basis for colored 
Hai et al.

silver-protein complex formation in stained polyacrylamide gels. Anal. Biochem. 141: 311-315.

Rauscher, F.J. III, L.C. Sambucetti, T. Curran, R.J. Distel, and B.M. Spiegelman. 1988a. Common DNA binding site for fos protein complexes and transcription factor AP-1. Cell 52: 471-480.

Rauscher, F.J. III, D.R. Cohen, T. Curran, T.J. Bos, P.K. Vogt, D. Bohmann, R. Tjian, and B.R. Franza, Jr. 1988b. Fos-associated protein $\mathrm{p} 39$ is the product of the jun proto-oncogene. Science 240: 1010-1016.

Petkovich, M., N.J. Brand, A. Krust, and P. Chambon. 1987. A human retinoic acid receptor which belongs to the family of nuclear receptors. Nature 330: 444-450.

Raymondjean, M., S. Cereghini, and M. Yaniv. 1988. Several distinct 'CCAAT' box binding proteins coexist in eukaryotic cells. Proc. Natl. Acad. Sci. 85: 757-761.

Reinberg, D., M. Horikoshi, and R.G. Roeder. 1987. Factors involved in specific transcription by mammalian RNA polymerase II. J. Biol. Chem. 262: 3322-3330.

Rosenfeld, P.J. and T.J. Kelly. 1986. Purification of nuclear factor 1 by DNA recognition site affinity chromatography. I. Biol. Chem. 261: 1398-1408.

Ryder, K., L.F. Lau, and D. Nathans. 1988. A gene activated by growth factors is related to the oncogene v-jun. Proc. Natl. Acad. Sci. 85: 1487-1491.

Samuels, M., A. Fire, and P.A. Sharp. 1982. Separation and characterization of factors mediating accurate transcription by RNA polymerase II. J. Biol. Chem. 257: 14419-14427.

Scheidereit, C., A. Heguy, and R.G. Roeder. 1987. Identification and purification of a human lymphoid-specific octamerbinding protein (OTF-2) that activates transcription of an immunoglobulin promoter in vitro. Cell 51: 783-793.

Short, J.M., A. Wynshaw-Boris, H.P. Short, and R.W. Hanson. 1986. Characterization of the phosphoenolpyruvate carboxykinase (GTP) promoter-regulatory region. I. Biol. Chem. 216: $9721-9726$.

Silver, B.J., J.A. Bokar, J.B. Virgin, E.A. Vallen, A. Milsted, and I.H. Nilson. 1987. Cyclic AMP regulation of the human glycoprotein hormone $\alpha$-subunit is mediated by an 18-base-pair element. Proc. Natl. Acad. Sci. 84: 2198-2202.

Staudt, L.M., H. Singh, R. Sen, T. Wirth, P.A. Sharp, and D. Baltimore. 1986. A lymphoid-specific protein binding to the octamer motif of immunoglobulin genes. Nature 323: 640643.

Struhl, K. 1987. The DNA-binding domains of the jun oncoprotein and the yeast GCN4 transcriptional activator protein are functionally homologous. Cell 50: 841-846.

Tsukada, T., J.S. Fink, G. Mandel, and R.H. Goodman. 1987. Identification of a region in the human vasoactive intestinal polypeptide gene responsible for regulation by cyclic AMP. I. Biol. Chem. 262: 8743-8747.

Yamamoto, K.R. 1985. Steroid receptor regulated transcription of specific genes and gene networks. Annu. Rev. Genet. 19: 209-252. 